\title{
15 Pillars of Islamic Good Corporate Governance for The Corporate Level
}

\author{
Maulidah Narastri \\ \{maulidah@untag-sby.ac.id\} \\ University of 17 Agustus 1945 Surabaya, Indonesia
}

\begin{abstract}
The purpose of this paper is to be applied by implementing 15 pillars in Islamic good corporate governance that can be applied to corporate distribution both conventionally and sharia. 15 pillars have been contained in the Qur'an which can be applied both conventionally and sharia. The Islamic good corporate governance pillar is Khilafah, Religion, Shura', Tauhid, Taqwa and Pleasure, Tawazun, Prosperity, Accountability, Reliability, Transparency, Trustworthiness, Responsibility, Independence, and Justice. The method used in this paper is a critical publication supported by scientific literature and the arguments provided in the Holy Qur'an. This article is expected to be able to contribute to be applied in entities that have a standard of cooperation both conventionally and sharia.
\end{abstract}

Keywords: Good corporate governance, sharia, corporate level.

\section{Introduction}

Good Corporate Governance (GCG) is a topic that is widely discussed, studied, and discussed in various books, research, and conferences at national and international levels. The GCG theory includes five fundamental principles, namely: 1) transparency; 2) accountability; 3) responsibility; 4) independence; and 5) fairness. According to the Organization for Economic Corporation and Development (OECD) (2004) cited from Jumansyah and Syafei (2013), the principle of GCG can help promote sound business practices. The GCG principle has a system that regulates the duties and obligations of all company elements. Starting from the board of commissioners, the board of directors to all other stakeholders [1]. The corporate governance that was applied for the first time in Indonesia was with a conventional system, but recently the new system began to emerge and adapted to the needs of business entities which were also increasingly numerous, the system was sharia-compliant corporate governance. the sharia system prioritizes three sources, namely alquran, hadith, and ulama scholars. According to Budiman (2018), the three main sources of Islam are: the Koran, the hadith and the ijma have arranged various aspects of worship until muamalah [2]. The Qur'an has taught the principles of corporate governance long before the theory of GCG was put forward. In the Qur'an, some many aspects and principles can be used to create the ideal environment of GCG without forgetting Islamic Shari'a. Topics regarding GCG tend to be investigated in quantitative ways. With the existing theory, the data obtained are tabulated in such a way as to produce various interpretations depending on which company will be the research site. All theories with conventional principles are used, become guidelines, to become a mecca for the company to become an ideal work environment. In fact, when studying and studying GCG from another perspective, it will be able to be emulated the principles of GCG have been arranged in such a way in The Qur'an 


\section{Previous research}

Danladi Yusuf et al [3] examined the topic of Islamic good corporate governance under the title A Conceptual Study on Islamic Corporate Governance Model in Curtailing Bank's Fraud. This study discusses concepts, frameworks, fraud structures and two challenging theories such as fraud triangle theory and fraud diamond theory [3]. Hasan [4] examines corporate governance which is reviewed in a western and Islamic perspective. Hasan further stated the model of corporate governance in terms of Islam has unique features and presentation compared to western concepts and European models [4]. Hasan [4] examined the basic elements of corporate governance in terms of Islam by comparing aspects of the conceptual definition, epistemology, corporate objectives, nature of management, and corporate structure [4]. Indrawaty et al [5] examined the implementation of Islamic corporate governance and Islamic social reporting on Islamic financial institutions. Researchers conduct research based on literature studies and based on research results with similar themes. Several studies have been built to assess how effective and how decisive Islamic corporate governance is in Indonesia [5].

\section{Conventional good corporate governance concept}

According to the National Governance Policy Committee [6], corporate governance is a set of rules or rules that are useful to encourage the achievement of corporate sustainability through management based on the principles of transparency, accountability, responsibility, independence, and fairness and equality. Furthermore, according to the national policy committee, good corporate governance is also needed to encourage the empowerment of functions and independence of each part of the company, namely the board of commissioners, directors and general meeting of shareholders [6]. According to the organization for economic cooperation and development [7] good corporate governance is a system that is applied to direct and control the company's business activities. Corporate governance regulates all rights regarding the division of duties, rights, and obligations of those who have authority and interests in the life of the company, including shareholders, boards, managers, and all members of stakeholders who are not part of shareholders [7]. The concept of conventional corporate governance has five principles, namely transparency, accountability, reliability, independence, and fairness. The five principles are expected to make the company a highquality company and going concern for a long time.

\section{Sharia good corporate governance concept}

The first origin or experiment in the concept of good corporate governance has actually existed and been implemented since the time of Ali bin Abi Talib r.a. narrated in that era there was a figure named Malik Al-Ashtar. Malik was someone who was appointed governor in Egypt. Malik's appointment is not without reason. According to the book The Voice of Human Justice chapter 22, written by George Jordac, Malik is someone who upholds honesty, trustworthiness, and transparency that is used as a tool to collect taxes, fight enemies of the state, prosper the population, and prosper the country at the start (Malik does not take office long because it was killed by enemies of Islam) [8]. Honesty and transparency are the beginning of the implementation of good corporate governance that can be applied in any country. However, the conventional concepts that have existed so far seem to be insufficient to create the right governance. Development and breakdown of the five principles are needed. according to Yusuf et al [3], corporate governance refers to the relationship between the 
corporation and its constituents. The Islamic Corporate Governance (ICG) model is applied in a wider constituency. Because it is applied in a wider constituency, there are aspects of sharia law on property and contractual rights. While in the conventional CG concept, there is the term 'shareholder-centric'. The main focus of the ICG model is far broader which can reach customers, competitors, suppliers, and entrepreneurs, thus, the ICG model is far more suitable to be applied in the theory of corporate governance stakeholders [3].

\section{Methodology}

This paper is written using library study methods and critical reviews based on the phenomenon of the application of good corporate governance to companies in Indonesia and the theories of good corporate governance that have been proposed so far. The author reviews the phenomenon supported by scientific literature and the arguments contained in the Holy Qur'an, hadith, and scholars' ijma

\section{Islamic good corporate governance}

\subsection{Khilafah}

Khilafah can be interpreted as a system of leadership that can be applied on all fronts because it is very general. The Khilafah has the characteristics of Islamic laws that are based on benefits for all people so that they can be applied in the scope of sharia and conventional. The narration of Buchari Muslim from Ibn Umar R.a said: I have heard the Messenger of Allah said: everyone is a leader and will be held accountable for his leadership. Ahead of state will be held accountable for the people he leads. A husband will be asked about the family he leads. A wife who cares for her husband's household will be asked about his responsibilities and duties.

\subsection{Religion}

According to Ramli, T [9] Religion is defined as attitudes and behaviors that are obedient and obedient in carrying out the religious teachings that they embrace [9]. Religious implementation in good corporate governance is always obeying every regulation that exists for the good of the corporate environment. as stated in the Qur'an the letter An-Nisa verse 58: in fact Allah tells you to deliver the mandate to those who have the right to receive it, and (tell you) when setting a law among men so that you will keep the law among men so that you determine justly. Verily, Allah has given the best teaching to you, for Allah is all-hearing, allseeing.

\subsection{Shura'}

According to the book Mu'jam maqayis al-lughah page 3226 , shura is interpreted as revealing and exposing something or taking something. Shura implementation in good corporate governance is an existing policy and information that must be delivered with transparency and honesty [10]. Al-qur'an Ash-Shura (42) verse 38: And (for) those who accept (obey) the call of their Lord and establish prayer, while their affairs are (decided) by musyawarat between them; and they spend part of the sustenance that We give them

\subsection{Tauhid}


In terminology, tauhid means is Islamic aqeedah which explains and states the oneness of Allah. Viewed from a monotheistic perspective, economic actors in business entities from the micro to corporate scope are trustees. Therefore, all activities and behaviors of businesspeople must obey Allah's rules, especially in realizing good corporate governance. Al-Qur'an Surat Az-Zumar (39) verse 38: And truly if you ask them: "Who created the heavens and the earth?", They surely answered: "Allah". Say: "Then explain to me what you exclaim besides Allah, if Allah wants to bring harm to me, can your idols remove the harm, or if God wants to give me mercy, can they withhold His mercy? Say: "Allah is sufficient for me." To Him is the person who surrenders.

\subsection{Taqwa}

In terminology, taqwa is the concept of believing in Allah, justifying it, and fearing Allah. Taqwa can be implemented in honesty activities in order to realize good corporate governance by doing what is right, and avoiding wrong activities. Alqur'an Surat At-Tawbah (9) verse 109: So do those who erect their mosque based on fear of Allah and His pleasure are good, or do those who build their buildings on the edge of a ravine collapse, then the building fell with him into Hell's Fire. And God does not give guidance to those who do wrong

\subsection{Pleasure}

Pleasure according to the language is an attitude of sincerity and accepts all the provisions of God, calm in facing all kinds of trials and always trying and not easily discouraged. Good implementation in good corporate governance is in making policies, should be made on the basis of mutual benefits and not being greedy and concerned with the parties themselves. Alqur'an Surat At-Tawbah (9) verse 109: So do those who erect their mosque on the basis of fear of Allah and His pleasure are good or do those who build their buildings on the edge of a ravine collapse, then the building fell with him into Hell's Fire. And God does not give guidance to those who do wrong

\subsection{Tawazun}

Tawazun in terminology is a balance of one's attitude to choose a balanced and fair position in the face of anything in life. Implementation of tawazun's attitude in good corporate governance is that business people must create an ecological balance in their work and the surrounding environment. This is because the company also lives side by side with the community so that no party can be harmed. Al-qur'an Surat Ar-Rahman (55) verses 7-9: And Allah has exalted the heavens and He put the balance (justice); So that you do not overstep the balance sheet; And keep the scales fairly and do not reduce the balance.

\subsection{Prosperity}

According to language is a condition where all elements of society are in a stable, prosperous, and sufficient condition. Implementation of Prosperity being in good corporate governance is a company must realize a good environment through policies that are made based on the conditions of existing employees. Conclusion of Imam Ghazali: maintenance of religion (hifdzud-din); soul maintenance (hifhzun-nafs); maintenance of reason (hifhzul-'aql; maintenance of offspring (hifhzun-nasl); maintenance of property (hifhzul-maal) 


\subsection{Accountability}

Accountability can be interpreted as a form of accountability from companies that should present financial and non-financial information in a clear and good manner. Implementation of accountability in good corporate governance is the control of the system among the fields of supervision that exist within the company. The principle of accountability can be applied in both conventional and sharia systems because accountability is also contained in orders within the Islamic religion. From Umar Ibnul Khattab R.A he said: Rasulullah SAW said: "Hold a calculation against yourself before you count".

\subsection{Reliability}

According to language, reliability is a condition where an entity can be relied upon and consistent in assessing or measuring everything. Islam commands anyone to be trustworthy and reliable in various situations. Al-quran Surat Al-baqarah (2) verse 283: If you are on a journey (and are not in cash) while you are not getting a writer, then there is a dependable item held (by the debtor). But if some of you trust some of the others, then let those who believe fulfill their mandate (debt) and let them fear Allah Allah; and do not (the witnesses) hide the testimony. And whoever hides it, surely he is a sinner; and God knows what you do.

\subsection{Transparency}

Transparency is a demand in all fields. Not only in the field of business, but also in the person of every human being. Openness and accountability in every act and behavior must be done in order to produce something good too. Transparency is needed in corporate governance to produce quality information produced by the company. Al-quran Surat Hud (11) verse 84: And to (the people) Mad-yan (We sent) their brother, Shu'aib. He said: "O my people, worship God, there is no God for you but Him. And do not reduce the measure and the scales, for I see you in a good condition, and I am afraid of you the punishment of a day of destruction (doomsday ) ".

\subsection{Trustworthiness}

Trust is a key that must be owned by the company in order to be able to stand and still get a place in the community. Banking is one of the business sectors that has the main capital in the form of trust in the corporate governance that they implement. Al-Qur'an Surat Al-Anfal (8) verse 27: O ye who believe, do not betray Allah and the Messenger (Muhammad) and (also) do not betray the messages entrusted to you, while you know

\subsection{Responsibility}

Responsibility is one form of corporate responsibility as part of the community to resolve existing regulations and rules. a sense of responsibility can be applied in good corporate governance in improving the system to regulate the mechanism of corporate information accountability to internal and external parties. Al-qur'an Surat Al-Baqarah (2) verse 282: O ye who believe, if you do not do it in cash for a specified time, let you write it down. And let an author among you write it correctly. And do not let the author be reluctant to write it as God taught it, meka should he write, and let the person who owes it to imitate (what will be written it), and let him fear the God of his Lord, and do not reduce it at all. If the person who owes is 
someone who is weak or weak (the situation) or he or she is unable to imitate himself, then let him assume honestly.

\subsection{Independence}

Independence is someone's impartiality to one of the parties to produce a certain goal. As a company, it is required to produce policies that do not favor anyone for any reason. Interventions from other parties must be eliminated by the company in the process of policymaking and company decision making. The company is also required to be unbiased in making policies and making decisions. Al-qur'an Surat Fushilat (41) verse 30: Surely those who say: "Our Lord is God" then they affirm their position, the angels will come down to them by saying: "Do not be afraid and do not feel sad, and cheer them up with Jannah which God has promised you ".

\subsection{Justice}

In Arabic, justice has several terms, some of which are most often used are haq. Justice has a resemblance to one of the pillars namely tawazun. The Qur'an also explains justice in a clear and lengthy manner in Surat Al-Anbiya (21) verse 47: We will install the right scales on the Day of Judgment, then there will be no harm to anyone in the least. And if (the practice) is only as heavy as the seeds of the saw, surely We bring (reward) it. And We are sufficient as calculators.

\section{CONCLUSION}

The application of good corporate governance in Indonesia is the key to making business entities competitive in the global market. Not only competitive, but can make business entities as a good and going-concern company. Fifteen pillars can be used as guidelines for companies for good corporate governance in addition to the five existing pillars. the development of the five pillars into fifteen pillars is based on the author of the needs in Indonesia, the pillars are: khilafah, religious, shura ', tauhid, taqwa and pleasure, tawazun, welfare, accountability, reliability, transparency, trustworthiness, responsiveness, independence and justice. All these pillars can be applied in conventional and sharia systems. because all these pillars are global in nature and are based on the Qur'an, hadith, and scholars' ijma. The content of the verses in the Qur'an, hadith, and scholars' ijma is intended to be used by all parties in the world. The suggestion from the author for the next research is that hopefully there will be scientific articles and research that discuss the success of good corporate governance after the application of some or all of the pillars the author has described in the current article.

\section{References}

[1] Jumansyah and A. W. Syafei, "Analisis Penerapan Good Governance Business Syariah dan Pencapaian Maqashid Shariah Bank Syariah di Indonesia," J. Al-Azhar Indones. Seri Pranata Sos., vol. 2, no. 1, pp. 25-38, 2013.

[2] S. A. Budiman, Akuntansi dan al-qur`an. 2018.

[3] A. Danladi Yusuf, "A Conceptual Study on Islamic Corporate Governance Model in Curtailing Bank’s Fraud.," Int. J. Econ. Financ. Manag. Sci., vol. 4, no. 6, p. 357, 2017.

[4] Z. Hasan, "Corporate Governance: Western and Islamic Perspectives," Int. Rev. Bus. Res. Pap., vol. 5, no. 1, pp. 277-293, 2009. 
[5] Indrawaty and S. M. Wardayati, "Implementing Islamic Corporate Governance (ICG) and Islamic Social Reporting (ISR) in Islamic Financial Institution (IFI)," Procedia Soc. Behav. Sci., pp. 338-343, 2016.

[6] K. Nasional, "Komite Nasional Kebijakan Governance," 2012.

[7] OECD, "G20/OECD Principles of Corporate Governance," In OECD Secretary-General. 2015.

[8] G. Jordac, The Voice of Human Justice.

[9] T. Ramli, Pendidikan Berkarakter. Bandung: Angkasa, 2013.

[10] A. A. H. A. I. F. . Zakaria, Mu'jam maqayis al-lughah. 